Dikirim: 14 Juni 2017 Diterbitkan: 1 Desember 2017

\title{
Evaluasi sistem pengelolaan limbah medis Puskesmas di wilayah Kabupaten Bantul
}

\section{Evaluation of community health center's medical waste management system in Bantul Regency}

Riang Lala Manila ${ }^{1} \&$ Sarto $^{2}$

\begin{abstract}
Purpose: This study aimed to evaluate the community health center medical waste management systems. Methods: This research was a qualitative study using a case study design in five community health center of Bantul District. Results: The management of medical waste in Bantul Regency is a new model using private party as a user (health cooperative) to hire services to the private transporter (CV. Jogya Prima Perkasa) to carry out the transportation and destruction of medical waste generated by health facilities of community health center, auxiliary health center and private health facilities. Consideration of Health Cooperation is a private institution belonging to Dinas Kesehatan and has a legal entity considered more flexible to bail out the initially issued funds to pay the financing of transport and extermination services to the transporter. Conclusion: Community health center medical waste management has followed the regulations. Health center has conducted medical waste management starting from the sorting, collection, packaging, storage, and transport. There should be improvements in some aspects, especially the creation of garbage dump for community health center that do not have them yet, while community health center who already have garbage dump need to make improvements according to the conditions specified.
\end{abstract}

Keywords: medical waste; community health center; evaluation

\footnotetext{
${ }^{1}$ Departemen Perilaku Kesehatan, Lingkungan, dan Kedokteran Sosial, Fakultas Kedokteran, Universitas Gadjah Mada (Email: manilarianglala651@gmail.com)

${ }^{2}$ Departemen Teknik Kimia, Fakultas Teknik, Universitas Gadjah Mada
} 


\section{PENDAHULUAN}

Pajanan limbah layanan kesehatan dapat mengakibatkan penyakit atau cidera petugas kesehatan, pasien, pengunjung dan masyarakat disekitar lingkungan fasilitas kesehatan (1,2). Meskipun proporsi limbah medis yang masuk ke dalam kategori limbah berbahaya hanya sebesar 15-25\%, tetapi risiko yang ditimbulkan cukup besar. WHO memprediksi risiko limbah benda tajam sebesar 1\% dari total limbah kesehatan pada tahun 2000. Hal ini menjadi resiko karena mampu menyebarkan infeksi hepatitis B dan hepatitis C (3).

Pengelolaan limbah medis puskesmas memiliki permasalahan yang cukup kompleks mengingat sumber daya yang terbatas yang di miliki oleh Puskesmas. Pengelolaan limbah medis di Puskesmas menggunakan metode insenerasi yang menimbulkan masalah pencema-ran udara dan kebisingan. Pengelolaan limbah padat perlu pengelolaan yang baik dan benar. Namun pemusnahan dengan incenerator yang beroperasi dibawah suhu $1.000 \mathrm{C}$ berpotensi menghasilkan emisi dioksin, zat kimia yang bersifat persisten, akumulasi dan beracun serta berdampak besar pada lingkungan dan kesehatan (4).

Penelitian lain menemukan pemanfaatan incenerator untuk limbah medis masih berfungsi dan dimanfaatkan, tetapi sudah tidak stabil sehingga bisa menghasilkan polusi di wilayah sekitar (5). Institusi yang memproduksi limbah medis harus secara sukarela membuangnya atau melakukan outsource ke perusahaan pembuangan sampah swasta (6). Hal ini sesuai dengan Peraturan Pemerintah Nomor 101 Tahun 2014 tentang pengelolaan limbah bahan berbahaya dan beracun.

Produksi sampah Puskesmas tahun 2009 yang dihasilkan sebesar $71 \%$ dari total produksi sampah medis di Kabupaten Bantul dan cenderung meningkat setiap tahun (7). Penanganan limbah medis limbah B3 untuk Puskesmas dan jaringannya kebawah di wilayah Kabupaten Bantul telah mengadakan kerjasama dengan pihak swasta dalam hal pengangkutan dan pemusnahan.

\section{METODE}

Penelitian kualitatif ini menggunakan rancangan studi kasus. Teknik pengambilan sampel menggunakan purposive sampling. Subyek penelitian adalah Kepala Bidang P2PL Dinas Kesehatan Kabupaten Bantul (1 Orang), Kepala Seksi Penyehatan Lingkungan (1 orang), Sekretaris Koperasi Kesehatan Bantul (1 orang), Kepala
Puskesmas (5 orang), sanitarian (5 orang), Petugas pelaksana pengelolaan limbah di Puskesmas (5 orang).

Instrumen yang digunakan adalah pan $\neg$ duan wawancara mendalam, voice recorder, lembar pedoman check list, kamera, data sekunder lain sebagai pendukung informasi dengan mengikuti rapat evaluasi pengelolaan limbah dan mencatat hasil rapat. Data dianalisis dengan mengategorikan jawaban responden dalam bentuk kuotasi, dan memberi kode untuk menyampaikan kejadian yang ada. Hasil wawancara yang didapatkan dianalisis, dipertajam kembali dengan hasil observasi ataupun studi data sekunder.

\section{HASIL}

\section{Pengelolaan limbah medis di Kabupaten Bantul}

Pengelolaan limbah medis di Bantul tahun 2005 menggunakan incenerator yang ditempatkan pada empat lokasi: Puskesmas Kretek, Srandakan, Piyungan dan Imogiri I. Dalam perkembangannya hanya dua incenerator yang berfungsi: Srandakan dan Kretek. Incenerator yang digunakan menimbulkan dampak lingkungan sekitar berupa abu, bau, suhu, kebisingan dan pencemaran udara. Masalah lain adalah pemberlakuan izin operasional incenerator oleh Badan Pengelolaan Lingkungan Hidup (BPLH) yang berat untuk dipenuhi karena Puskesmas tidak mempunyai sumber daya operasional yang cukup.

Dinas Kesehatan menghentikan pengoperasian incenerator di Kretek dan Srandakan dan mencari cara lain yang lebih efisien dan tidak melanggar peraturan. Dinas Kesehatan menyusun kerjasama seluruh Puskesmas dengan pihak ketiga swasta dalam hal pengangkutan dan pemusnahan.

"Sebagai langkah awal, kita mulai mencari pihak ke-tiga yang berperan sebagai transpoter dalam pe-nanganan

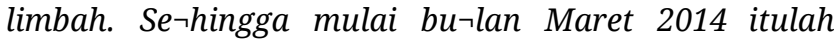
limbah kita mulai diᄀangkut oleh PT...dulu CV.Jogya Prima Perkasa”. (R3).

Limbah medis dihasilkan bukan hanya berasal dari Puskesmas saja, tetapi berasal dari klinik swasta, BP umum, dokter praktek swasta yang berada di wilayah kerja Puskesmas masing-masing. Kerjasama dengan pihak ketiga menyangkut hak dan kewajiban dalam bentuk perjanjian tentang jasa pengelolaan limbah B3.

\section{Kelembagaan}

Manajemen pengelolaan limbah medis di Puskesmas secara struktural berada di bawah Seksi 
Kesehatan Lingkungan Dinas Kesehatan. Dinas kesehatan melakukan perencanaan pengelolaan, sementara pelaksanaan pengelolaan limbah medis diserahkan ke Puskesmas.

Puskesmas sebagai penanggung jawab wilayah harus memastikan limbah medis yang dihasilkan oleh fasilitas kesehatan di bawahnya seperti puskemas pembantu, pondok bersalin desa, bidan desa serta fasilitas kesehatan swasta. Dinas Kesehatan memegang peranan penting dalam hal perencanaan awal untuk mencarikan rumusan yang tepat mengatasi masalah limbah medis yang ada di Puskesmas.

"Ya, malah anu itu yang mencarikan solusi yang me-rencanakan malah kita, karena kayak Puskesmas kemudian fasyankes yang ada di wilayah puskesmas mereka itu kan nggak berpikiran sampai kesana, kita yang mengetahui aturan diatas kita yang merencanakan.(R2).

Dalam pelaksanaannya manajemen pe-ngelolaan limbah medis diserahkan ke Koperasi Kesehatan milik Dinas Kesehatan Kabupaten Bantul untuk melakukan kerjasama dengan pihak ketiga dalam hal ini adalah CV. Jogya Prima Perkasa (transpoter) dan PT. Wastec Internasional (pemusnahan) dengan pertimbangan limbah medis yang berada di Puskesmas bukan hanya berasal dari lingkup Puskesmas seperti polindes dan pustu tetapi juga berasal dari pihak fasyankes swasta.

"Itu ceritanya kenapa kita bisa menyalahi pera-turan begini. Kalau dengan PP nya itu, Peraturan Pemerintah mengenai hal ini kebetulan harus bekerjasama dengan pihak ketiga. Kerjasama dengan pihak ketiga itu bisa dengan pengolah ataupun trans-porternya yang sudah berizin. Kendalanya adalah kita itu di Bantul ini kan banyak puskesmasnya itu kecil, kemudian banyak di wilayah puskesmasnya itu karena dia punya tugas membina pasien yang ada di wila $\neg y a h n y a, k l i n i k-k l i n i k$ kecil, dokter praktik, maka dia punya kewajiban tentang itu. nah di satu sisi peraturan PP tadi menjadikan transporter atau pengolah limbah tadi untuk bekerjasama itu syaratnya mahal biayanya.” (R2)

Pertimbangan biaya menjadi alasan Puskesmas dan fasilitas kesehatan swasta bekejasama karena pihak transporter menerapkan standar biaya minimum dan standar jumlah berat limbah medis yang diangkut dari tiap faskes sebanyak minimum $10 \mathrm{~kg}$ sedangkan banyak Puskesmas kecil dan faskes swasta kecil yang jumlah limbah medis tidak mencapai jumlah minimum $10 \mathrm{~kg}$. Dinas Kesehatan belum mempunyai mekanisme hukum yang jelas untuk menerima jasa pembayaran dari Puskesmas dan faskes swasta dibawahnya.
Koperasi melakukan pembayaran jasa pengangkutan dan pemusnahan setiap bulan kepada pihak tranporter. Koperasi kesehatan akan mengirimkan tagihan manifest kepada Puskesmas. Berdasarkan manifest ini pihak Puskesmas dalam hal ini sanitarian akan melakukan komunikasi kepada faskes swasta mengenai pembayaran kepada pihak koperasi. Koperasi kesehatan melakukan talangan dana terlebih dahulu untuk pembayaran karena koperasi mempunyai ketersediaan dana dan bersifat fleksibel. Pengangkutan limbah medis ini oleh transporter swasta dipusatkan di masing - masing Puskesmas sehingga faskes swasta mengirimkan limbah nya untuk dikumpulkan di tempat penampungan puskesmas untuk selanjutnya diangkut dan dimusnahkan oleh transpoter swasta. Badan Pengelolaan Lingkungan Hidup berperan dalam perizinan, pengawasan dan pembinaan. BPLH Kabupaten Bantul menerapkan kewajiban fasilitas kesehatan harus bekerjasama dengan pihak ketiga untuk pengelolaan limbah.

\section{Sumber daya manusia}

Jumlah tenaga sanitarian di Kabupaten Bantul sebanyak 60 orang yang tersebar di Puskesmas, Rumah Sakit maupun di Dinas Kesehatan. Setiap Puskesmas rata-rata mempunyai sanitarian sebanyak 1 orang dengan status sebagai Pegawai Negeri Sipil.

Tenaga sanitarian di Puskesmas bertanggung jawab mengelola kebersihan dan kesehatan lingkungan, pengelolaan limbah medis B3, dan pengelolaan limbah non medis. Sanitarian Puskesmas bertanggung jawab memantau tenaga cleaning service.

Jumlah cleaning service di Puskesmas sebanyak satu sampai tiga orang. Cleaning service mempunyai jadwal pengumpulan limbah medis setiap ruangan untuk diangkut ke tempat penampungan sementara. Status petugas cleaning service Puskesmas adalah pegawai honorer dan ada yang berstatus pegawai swasta. Petugas cleaning service Puskesmas ini rata-rata belum pernah mendapatkan pelatihan khusus mengenai limbah medis.

"Belum pernah dilatih. Ya dibilang kerjanya di Puskesmas. Kan sambil jalan kita tahu kalo sampah medis di sana, kalo bukan medis disitu”. (R9)

Sanitarian sudah melaksanakan tugas dan fungsinya walau belum dilengkapi dengan dokumen lengkap. Sanitarian mempunyai beban tugas ganda, sehingga sulit memantau kinerja cleaning service setiap 
harinya. Sanitarian bertanggung jawab menjaga kebersihan dan mengendalikan pembuangan limbah bahan berbahaya dan limbah rumah tangga. Beberapa Puskesmas belum menyusun surat keputusan uraian tugas ini.

"Nah ini dalam rangka administrasi ya mba. dalam rangka akreditasi tahun 2017 ya, kami kan mencoba membuat dengan standard semua. Memang pada tahun-tahun sebelumnya kita memang penugasanpenugasan, tapi belum ke SK. Tapi kalo rincian semua sudah ada SK nya. jadwal, penugasan, tupo-ksi, semua itu ada. Tapi SK nya justru yang belum. Itu yang kemaren. Tapi mulai tahun ini udah buka."(R4).

Puskesmas yang telah terakreditasi, kelengkapan surat keputusan penugasan sani-tarian, uraian tugas dan tanggung jawab serta protap telah disusun dengan baik sehingga dalam melaksanakan tugasnya seorang sanitarian mengikuti standar operasional yang telah disediakan.

\section{Regulasi}

Penanganan limbah medis di Bantul mengikuti Peraturan Presiden. Peraturan menyebutkan bahwa penghasil limbah B3 wajib melakukan pengumpulan dan pengolahan limbah dan apabila tidak dapat dilakukan, wajib untuk menyerahkan ke pengelola limbah B3 yang berizin. Pihak pertama adalah koperasi kesehatan KPN RI "Kesehatan" Bantul, dan pihak kedua adalah CV.Jogya Prima Perkasa, dan pihak ketiga adalah PT. Wastec. Internasional.

\section{Sarana Prasarana}

Sarana prasarana limbah medis meliputi tempat sampah limbah medis dan non medis, kantong plastik untuk penyimpanan limbah, tempat penampungan sementara, sapu, dan IPAL (instalasi pembuangan air limbah). Peralatan untuk pemilahan, pengumpulan, pengangkutan dan pemusnahan yang dig-nakan adalah tempat sampah berkode, wadah plastik berwarna, safety box, wheelbin, dan TPS.

\section{Pembiayaan}

Biaya jasa pengelolaan limbah medis sebesar Rp. 15.000/kg dengan harga sudah termasuk pajak PPN $10 \%$. Biaya jasa dibayarkan pihak pertama kepada pihak kedua paling lambat tujuh hari setelah tagihan invoice dikirim pihak pertama. Koperasi Kesehatan melakukan pembayaran jasa terlebih dahulu ke pihak kedua berdasarkan manifest yang dilakukan. Setelah melakukan pembayaran jasa, Koperasi Kesehatan mengirim rincian manifest ke Puskesmas dan faskes swasta yang bekerjasama dalam pengumpulan limbah. Pemilahan

Puskesmas di Kabupaten Bantul telah melakukan pemilahan limbah medis dan non medis. Wadah masing masing limbah telah diberi label limbah medis dan limbah non medis serta safety box untuk limbah medis tajam. Pemilahan limbah medis di puskesmas hanya dikategorikan menjadi dua jenis: limbah medis padat dan limbah medis tajam.

Tempat sampah medis Puskesmas B dilapisi plastik warna kuning, kuat dan tidak mudah bocor sedangkan Puskesmas A, C, D dan E hanya melapisi dengan kantong plastik biasa dengan warna lain dengan alasan persediaan plastik khusus wadah limbah habis. Tempat sampah medis berwarna kuning tidak dilapisi plastik sehingga ketika diangkut ke tempat penampungan sementara, cleaning service menyalin secara manual ke kantong plastik sehingga ditempat sampah medis masih tertinggal sisa cairan atau darah. Ini karena kurang ada supervisi kebersihan dan tidak ada inisiatif petugas medis melapor pada petugas cleaning service.

Petugas kesehatan dan pasien masih mencampur sampah medis dan non medis. Ketika mendapati kondisi tersebut cleaning service langsung memungut sampah yang tercampur itu dan memindahkan ke wadah yang seharusnya. Pada awal mengadakan kerjasama, transporter pernah komplain saat limbah medis dan non medis tercampur. Alasan ekonomis menjadi pertimbangan cleaning service Puskesmas C dan E untuk tidak menggabungkan plabote infuse ke dalam limbah medis tetapi dikumpulkan untuk dijual.

Plabote infuse masuk dalam kategori limbah medis, tetapi seiring peningkatan jumlah limbah plastik, maka plabote infuse didaur ulang. Dinas kesehatan merencanakan pengolahan plabote infuse untuk menghilangkan sifat infeksius, tetapi BPLH belum mensosialisasikan aturan baru itu, sehingga belum dilaksanakan.

\section{Pengangkutan}

Pengangkutan limbah medis melalui dua tahap: pengangkutan internal dan pengangkutan eksternal. Proses pengangkutan internal dilakukan oleh cleaning service setiap hari untuk dibawa ke penampungan sementara. Kegiatan itu dilakukan secara manual tanpa menggunakan alat dengan alasan jumlah limbah yang diangkut tidak besar. Limbah medis disimpan di 
wheelbin dengan kapasitas 30 liter, dimana tiap Puskesmas mempunyai wadah wheelbin sekitar dua sampai tiga buah.

Pengangkutan eksternal dilakukan transporter swasta menggunakan mobil box setiap satu bulan sekali. Limbah medis diambil langsung dari tempat penyimpanan sementara Puskesmas. Sebelum limbah dimasukkan ke dalam mobil box, limbah medis ditimbang dan dicatat oleh pihak koperasi kesehatan sebanyak dua rangkap. Limbah medis yang berada dalam wheelbin akan di`masukkan langsung ke dalam mobil kemudian dilakukan tukar wheelbin kosong dari transporter. Tetapi terkadang karena kapasitas mobil telah penuh maka kantong plastik dimasukkan dengan cara di disisipkan di mobil box. Pengangkutan limbah dilakukan transporter swasta menggunakan mobil box ukuran kecil dengan memudahkan mobil pengangkut untuk masuk ke area Puskesmas. Padahal melihat volume limbah medis yang dihasilkan semakin meningkat seharusnya pihak transporter perlu menambah kapasitas lebih besar.

\section{Penampungan}

Belum semua Puskesmas di Kabupaten Bantul memiliki tempat penampungan sementara limbah medis. Tempat penampungan sementara limbah medis ini belum memiliki pengatur suhu ruangan dimana dalam aturan sanitasi Rumah Sakit disebutkan penyimpanan limbah medis maksimal 2x24 jam karena sifat infeksius sedangkan limbah medis yang sifatnya kimia mencapai maksimal 90 hari sebelum dimusnahkan. Padahal jadwal pengangkutan limbah oleh pihak transporter dilakukan sekali dalam sebulan.

\section{Cakupan limbah}

Cakupan limbah medis setiap tahun mengalami peningkatan. Tercatat limbah yang terangkut tahun 2014 sebanyak $5.125 \mathrm{~kg}$ dengan 88 fasyankes swasta didalamnya. Pada tahun 2015 terjadi peningkatan menjadi $8.500 \mathrm{~kg}$ dengan fasyankes yang terlibat sebanyak 109.

\section{BAHASAN}

\section{Manajemen input pengelolaan limbah medis}

Pengelolaan limbah medis menggunakan model baru dengan melibatkan koperasi kesehatan sebagai user untuk menyewa jasa angkut pihak transporter swasta. Mekanisme ini digunakan karena Puskesmas tidak memiliki incenerator.
Pertimbangan memilih Koperasi Kesehatan sebagai mitra karena merupakan lembaga swasta milik Dinas Kesehatan dan memiliki badan hukum dianggap lebih fleksibel untuk menalangi dana yang dikeluarkan di awal untuk membayar pembiayaan jasa pengangkutan dan pemusnahan. Hal ini disebut dengan contracting out: tindakan yang dilakukan lembaga pemerintah untuk memperkerjakan dan membiayai agen swasta untuk menyediakan pelayanan tertentu daripada mengelola sendiri (8).

Faktor terpenting dalam memilih perusahaan penanganan limbah infeksius adalah harga yang ditawarkan harus kompetitif (9). Meskipun pihak swasta telah melakukan pengelolaan pembuangan limbah medis efektif, Puskesmas harus bertanggung jawab atas pembuangan limbah yang aman dan layak.

Dinas Kesehatan harus melakukan penilaian secara teliti kepada pihak swasta sebagai transporter dan pemusnahan. Item minimal yang harus dipenuhi adalah ketersediaan alat pembekuan, kontainer limbah medis tajam, frekuensi dan metode pembuangan dan pemusnahan serta kendaraan yang memenuhi syarat pengangkutan limbah medis. Untuk memastikan limbah medis yang diangkut telah dimusnahkan dengan benar, Koperasi Kesehatan, Puskesmas, Dinas Kesehatan, dan BPLH mengunjungi PT. Wastec..

Dinas Kesehatan tidak menghilangkan fungsi dan tanggung jawabnya sebagai pembina dengan mengadakan evaluasi setiap tahunnya. Evaluasi internal hanya melibatkan Puskesmas diwakili oleh sanitarian dan Dinas Kesehatan diwakili oleh seksi Kesehatan Lingkungan. Evaluasi eksternal dilakukan bertahap. Tahap pertama dilakukan antara Koperasi Kesehatan, Dinas Kesehatan, Puskesmas dan BPLH. Pada tahap selanjutnya dilakukan evaluasi antara Dinas Kesehatan, BPLH dan pihak transporter swasta.

Dinas Kesehatan melalui Puskesmas harus secara tegas memberi teguran kepada fasilitas pelayanan kesehatan swasta yang telah menandatangani perjanjian kerjasama pengelolaan limbah medis tetapi tidak rutin mengirim limbah ke Puskesmas. Dinas berperan melakukan pembinaan dan pengawasan.

\section{Manajemen proses pengelolaan limbah medis}

Pemilahan limbah medis menggunakan kode pelabelan dan warna yang dibedakan menjadi dua jenis: limbah infeksius dan limbah benda tajam. Hal ini berbeda dengan peraturan Menteri Lingkungan Hidup dan Kehutanan yang mengelompokkan limbah medis menjadi 9 jenis. Walaupun belum semua Puskesmas memiliki jenis limbah lengkap berdasarkan kriteria, 
tetapi setiap Puskesmas harus mengidentifikasi jenis limbah medis yang dihasilkan dari kegiatan pelayanan medis. Praktik pemilahan pada sumber aliran limbah harus diperkenalkan ke semua petugas kesehatan.

Pengumpulan limbah medis dilakukan setiap hari oleh petugas cleaning service sudah sesuai dengan aturan yang berlaku. Limbah medis dikumpulkan dari tiap ruangan, kantong wadah plastik diikat dan dimasukkan ke dalam wheelbin dan diletakkan di TPS.

Frekuensi pengangkutan eksternal yang dilakukan sebulan sekali oleh pihak transporter swasta masih menjadi masalah tersendiri. Peraturan Menteri Lingkungan Hidup dan Kehutanan nomor 56 Tahun 2015 tentang tatacara dan persyaratan teknis pengelolaan limbah B3 dari fasilitas pelayanan kesehatan disebutkan limbah infeksius, benda tajam dan limbah patologis tidak boleh disimpan lebih dari 2 hari untuk menghindari pertumbuhan bakteri, outrekasi dan bau. Apabila disimpan lebih dari dua hari limbah harus dilakukan desinfeksi kimiawi atau disimpan dalam refrigator suhu $0^{\circ} \mathrm{C}$ atau lebih rendah. Namun, belum semua Puskesmas memiliki TPS. Puskesmas belum memenuhi persyaratan untuk menyimpan limbah medis lebih dari dua hari karena tidak dilengkapi pengatur suhu untuk penyimpanan limbah infeksius.

Pengangkutan limbah dilakukan sebulan sekali karena terkendala pada masalah biaya. Pengangkutan limbah setiap hari tidak menutupi biaya operasional. Sementara, ketika memberlakukan sistem pengangkutan dua hari sekali maka biaya angkut yang dikeluarkan menjadi besar. Perlu solusi dengan mencari penawaran ke perusahaan lain yang bisa memberikan penawaran yang lebih baik. Alternatif lain dengan membuat tempat penampungan sementara di Puskesmas yang dilengkapi alat pengatur suhu.

\section{Cakupan limbah medis}

Secara jumlah cakupan pengelolaan limbah medis sudah mencakup seluruh wilayah di Kabupaten Bantul tetapi potensi jumlah limbah medis yang dihasilkan masih cukup besar mengingat belum semua fasyankes swasta melakukan kerjasama rutin pengiriman limbah.

\section{SIMPULAN}

Contracting out pengelolaan limbah medis menggunakan lembaga koperasi milik Dinas Kesehatan sebagai pihak penghubung Puskesmas dengan pihak transporter swasta. Peran Dinas Kesehatan sebagai koordinator dari Puskesmas harus ditingkatkan dalam evaluasi rutin pelaksanaan pengelolaan limbah medis berdasarkan aturan.

\section{Abstrak}

Tujuan: Penelitian ini bertujuan mengevaluasi sistem pengelolaan limbah medis Puskesmas. Metode: Jenis penelitian kualitatif ini menggunakan rancangan studi kasus di lima Puskesmas Kabupaten Bantul. Hasil: Pengelolaan limbah medis di Kabupaten Bantul merupakan model baru menggunakan pihak swasta sebagai user (koperasi kesehatan) untuk menyewa jasa kepada pihak transporter swasta (CV. Jogya Prima Perkasa) melakukan pengangkutan dan pemusnahan limbah medis yang dihasilkan oleh fasilitas kesehatan Puskesmas, Pustu, Polindes dan fasilitas kesehatan swasta. Pertimbangan Koperasi Kesehatan adalah lembaga swasta yang merupakan milik Dinas Kesehatan dan memiliki badan hukum dianggap lebih fleksibel untuk menalangi dana yang dikeluarkan awal untuk membayar pembiayaan jasa pengangkutan dan pemusnahan kepada pihak transporter. Simpulan: Perlu ada peningkatan dalam beberapa aspek terutama pembuatan TPS bagi Puskesmas yang belum memiliki, sementara Puskesmas yang sudah memiliki TPS perlu meningkatkan sesuai syarat yang ditentukan. Pengelolaan limbah medis Puskesmas sudah mengikuti peraturan. Puskesmas telah melakukan pengelolaan limbah medis yang dimulai dari pemilahan, pengumpulan, pengemasan, penyimpanan dan pengangkutan.

Kata kunci: limbah medis; Puskesmas; evaluasi

\section{PUSTAKA}

1. Adisasmito W. Sistem Manajemen Lingkungan Rumah Sakit. Jakarta: PT. Raja Grafindo Persada; 2009.

2. Adisasmito W. Audit Lingkungan $\mathrm{Ru} \neg$ mah Sakit. Jakarta: Rajawali Pers; 2008.

3. WHO. Pengelolaan Aman Limbah Layanan Kesehatan. Jakarta: EGC; 2005.

4. Habibi E, Taheri MR, Hasanzadeh A. Relationship between mental workload and musculoskeletal disorders among Alzahra Hospital nurses. Iran J Nurs Midwifery Res. Wolters Kluwer -- Medknow Publications; 2015;20(1):1-6.

5. Sudewi S. Pemanfaatan Incenerator Untuk Limbah Medis Puskesmas di Kabu $\neg$ paten Bantul (Studi Kasus Puskesmas Srandakan). Universitas Gadjah Mada; 2013.

6. Liao C-J, Ho CC. Risk management for outsourcing biomedical waste disposal - Using the failure mode and effects analysis. Waste Manag. 2014 Jul;34(7):1324-9. 
7. Sukantoro. Evaluasi Pengelolaan Limbah Klinis Tajam Puskesmas di Kota Yogyakarta. Universitas Gadjah Mada; 2008.
8. Murti B. Contracting out pelayanan kesehatan. J Manaj Pelayanan Kesehat. 2006;9(3).

9. Garcia-Prado A, Chawla M. The impact of hospital management reforms on absenteeism in Costa Rica. Health Policy Plan. 2006;21(2):91-100. 
Berita Kedokteran Masyarakat, Volume 33 No. 12 Tahun 2017 